\title{
Jesus, Judas en 'n stukkie brood. Die betekenis van 'n gebaar in Johannes 13:26
}

\author{
D F Tolmie \\ (Universiteit van die Vrystaat)
}

\section{ABSTRACT}

Jesus, Judas and a morsel. Interpreting a gesture in John 13:26

In the Gospel according to John, Jesus identifies Judas as the traitor in a highly dramatic fashion by handing him a morsel. Although Johannine scholars do not often comment on this gesture, in cases where they do, one finds a surprisingly wide range of interpretations, for example, it is interpreted as a gesture denoting Judas as an outsider, a gesture of friendship, a gesture indicating baptism or the eucharist, even a gesture indicating that Judas shares eucharist with the Satan. In this article the interpretation of this gesture is considered. After a discussion of the characterisation of Judas in the Gospel according to John, the gesture itself is considered. Its possible background in antiquity is discussed, which is then followed by an interpretation of the gesture as a gesture of friendship. It is also suggested that the gesture could also be viewed as (another) example of Johannine irony.

\section{DIE PROBLEEM}

In die Johannesevangelie ontmasker Jesus die verraaier op 'n dramatiese manier deur vir hom 'n stukkie brood' te gee. Die meeste kommentatore skenk gewoonlik nie veel aandag aan Jesus se gebaar nie, maar die enkeles wat dit wel interpreteer, doen dit op heelwat verskillende maniere. Enkele voorbeelde om dit te illustreer:

Hirsch (1936:338-339) interpreteer die gebaar as 'n manier om aan te dui dat Judas 'n buitestaander is:

Jesus taucht ein Brotstück in die Schüttel und gibts Judas. Der Hausgenosse taucht sein Brot selber ein. Jesu Handlung kennzeichnet Judas also höflich als den Fremden, der an der Schüttel nur Gastrecht hat.

\footnotetext{
$1 \quad$ Streng gesproke beteken die woord wat gebruik word (y wmi on) nie 'n stukkie brood nie, maar enige stukkie kos. Soos wat Schnackenburg (1979:35) egter tereg aandui, kan 'n mens egter aanvaar dat die evangelis aan brood dink omdat hy waarskynlik die aanhaling wat hy in vers 18 gebruik (mou ton a [ t on), in gedagte het.
} 
Brown (1984:578) interpreteer dit presies op die teenoorgestelde manier - as 'n gebaar van gasvryheid:

What John describes is a basic gesture of Oriental hospitality, as can be seen from Ruth ii 14. Indeed, Jesus may be extending to Judas a special act of esteem whereby a host singles out a guest whom he wishes to honor and picks out for him from the common plate a choice morsel of food. But this sign of Jesus' affection, like the act of love that brought him into the world, brings Judas to the decisive moment of judgement.

Brodie (1993:453) interpreteer Jesus se gebaar nie net as iets wat liefde aandui nie, maar verduidelik ook wat hy dink Jesus deur middel van die gebaar wou regkry:

[T]he morsel did not destroy Judas' freedom, did not push him into the grip of Satan. On the contrary, since it was about as gentle and affectionate a gesture as one could imagine - like something a parent would do for a child or one lover for another - it was an effort to recall Judas from his developing entanglement with Satan.

'n Verdere moontlikheid is om die gebaar sakramenteel te interpreteer, as 'n verwysing na óf die doop óf die Nagmaal. As 'n voorbeeld van iemand wat dit as 'n verwysing na die doop interpreteer, kan Howard-Brook (1994:304) genoem word: ${ }^{2}$

It is an ironic "baptism," for Jesus' act of dipping will lead the recipient to be entered by Satan, not God.

'n Verdere voorbeeld van iemand wat dink dit verwys na die doop, is Buckley (1998:60-71) wat die gebeure in 13:26 op 'n tweeledige manier interpreteer. Enersyds is dit volgens hom 'n vergiftigingstoneel en andersyds 'n voedingstoneel aangesien Jesus vir Judas met sy eie liggaam, 'n "gedoopte liggaam", voed:

As a result of the food, "after the morsel" (John 13:27), Satan enters Judas, which I take as a direct poisoning. Recall that Satan had already influenced Judas' heart (John 13:2). Now, Jesus ensures that Satan also enters Judas on a deeper level, into his guts, his digestive system (Buckley 1998:62).

$2 \quad$ Kyk ook Bohnen (2000:259-283). 
Not only is Jesus the bread, but the dipped bread presented to Judas is essentially a baptized body. For the verb "to dip" is the same as the verb "to baptize." In my opinion, then, Judas, obtains a "baptized Jesus",... (Buckley 1998:67).

As 'n voorbeeld van iemand wat die gebeure binne 'n Nagmaalkonteks plaas, kan Moloney (1998:22-23) genoem word:

There is intertextuality between the gift of the morsel and Eucharistic traditions in the Johannine community held in common with the early church. Eucharist is a subtheme to the morsel, just as baptism is a subtheme to the footwashing. Within the context of a meal indicated as eucharistic, Jesus gives the morsel to the most despised character in the Gospel's narrative: Judas. ... Jesus' never-failing love for such disciples, a love that reached out even to the archetype of the evil disciple, reveals a unique God.

Talbert (1992:198) neem die klem op 'n Nagmaalskonteks 'n stappie verder:

The meal has become for Judas not communion with Jesus but with the devil. There is a warning in these words. Judas has eaten with Jesus (vv. 18, 26-27, 30), yet he is the possession of Satan ... This would seem to imply that eating with Jesus does not guarantee one's discipleship, as Judas' example shows.

'n Nagmaalsinterpretasie kan selfs nog verder geneem word, soos wat in die geval van Wrede (1907:136) gebeur:

Der Bissen scheint eine magische Wirkung auf den Jünger zu üben. Es is eine Art satanisches Sakrament, das Judas genie $\beta$ t.

Uit bogenoemde blyk duidelik dat daar verskil van mening oor die interpretasie van Jesus se gebaar is. Die doel van hierdie artikel is om die verskillende interpretasies van Jesus se gebaar krities te evalueer, aan te dui watter interpretasie die beste vanuit die teks van die Johannesevangelie verantwoord kan word en om te poog om die interpretasie van Jesus se gebaar 'n stap verder te neem. Om dit te doen, word eers aan die karakterisering van Judas in die 
Johannesevangelie aandag gegee (Afdeling 2) waarna die interpretasie van Jesus se gebaar ondersoek sal word (Afdeling 3).

\section{DIE KARAKTERISERING VAN JUDAS IN DIE JOHANNESEVANGELIE}

In die Johannesevangelie hoor ' $n$ mens slegs agt keer van Judas $(6: 70-71 ; 12: 4-6 ; 13: 2 ; 13: 11 ; 13: 26-30 ; 17: 12 ; 18: 2-6$ en $21: 20)$ :

Judas word die eerste keer in Johannes 6:70-71 genoem; in 'n toneel wat Culpepper (1983:125) tereg as 'n “context of mass defection" beskryf: Baie van Jesus se dissipels vind sy lering te moeilik om te aanvaar. Jesus gaan egter voort met sy lering wat tot gevolg het dat baie van sy dissipels besluit om Hom te verlaat. In reaksie op Jesus se vraag of die twaalf nie maar ook wil weggaan nie, bely Petrus dat Jesus die "Heilige van God" is wat die woorde van die ewige lewe het. Jesus se reaksie hierop is egter allesbehalwe bemoedigend: "Het Ek nie julle twaalf gekies nie? En een van julle is 'n duiwel!" Die leser ${ }^{3}$ word ingelig dat Jesus van Judas, die seun van Iskariot, praat, want hy, een van die twaalf, sou vir Jesus verraai. Vir die karakterisering van Judas is dit belangrik om raak te sien dat die dissipels op hierdie stadium nog nie weet wie die "duiwel" is nie of presies wat hy gaan doen nie. Dit word net aan die leser bekend gemaak deur 'n sydelingse opmerking (Engels "aside") waarin Jesus intern gefokaliseer word ${ }^{4}$. Verder is dit opvallend dat Judas op 'n baie negatiewe manier gekarakteriseer word. Om iemand in daardie tyd 'n "duiwel" te noem, was een van die ergste maniere om iemand te etiketteer (Malina \& Rohrbaugh 1998:151-152). In hierdie geval word die etikettering deur die Hooffiguur gedoen, deur middel van

3 Met "leser" word in hierdie artikel deurgaans die "implisiete leser" bedoel, dit wil sê die teëhanger van die "implisiete outeur". Beide begrippe word in hierdie artikel primêr tekstueel verstaan. Met "implisiete outeur" word die organiserende beginsel in die teks bedoel - dit wat verantwoordelik is vir die totale organisasie van al die narratiewe elemente in die teks. Die "implisiete leser" is die intra-tekstuele literêre konstruk wat as die teenpool van die implisiete outeur funksioneer, maar wat temporeel beperk is in die sin dat dit as't ware episode vir episode "ontwikkel" soos wat die verhaal vorder. Dit gaan dus oor twee perspektiewe op die verhaal, naamlik die verhaal as oorkoepelende geïntegreerde geheel en die verhaal soos wat dit temporeel, episode vir episode, ontvou. Kyk Staley (1988:33-34) vir 'n vollediger beskrywing.

4 Met "fokalisasie" word bedoel die bepaalde blikpunt van waaruit gebeure beskou word. Kyk Tolmie (1999:29-38) vir 'n vollediger bespreking. 
direkte karakterisering. Omdat die Hooffiguur tot sover as absoluut betroubaar uitgebeeld is, sal die leser sal dus geen rede hê om die inligting te betwyfel nie. Dit is ook belangrik om raak te sien dat die ekstra inligting wat in vers 71 aan die leser voorsien word, op so 'n manier geformuleer word dat die verraderlike aard van Judas se optrede beklemtoon word. Sy deelwees van die twaalf word direk met sy daad van verraad gekontrasteer: out o gar elnellen paradidonai a ut on, eif ek twh dwdeka. Die eerste keer wat Judas eksplisiet binne die narratiewe wêreld uitgelig word, kry die leser dus reeds die belangrikste inligting wat nodig is om dié karakter te evalueer.

Judas verskyn weer in hoofstuk 12 wanneer hy protesteer dat 'n mens die nardus-olie waarmee Jesus se voete gesalf is, vir 300 denarii kon verkoop het en die geld vir die armes kon gegee het. Ten opsigte van die karakterisering van Judas is die volgende belangrik: Eerstens word hy op dieselfde manier gekarakteriseer as wat in 6:71 gebeur het, naamlik dat sy daad van verraad met sy deelwees van die twaalf gekontrasteer word: 'I ouda ol J skariwth eif [ek] t wh̀ maf ht wh a uf ou, ol melv wn a uf on paradidona i (12:4). Tweedens word die opmerking wat hy maak, gebruik om hom in 'n negatiewe lig te stel, want in 'n sydelingse opmerking aan die leser word Judas intern gefokaliseer en sy ware motiewe onthul: hy is ' $n$ dief wat uit die gesamentlike beurs waarvoor hy verantwoordelik was, gesteel het. Hierdie inligting word nie gebruik om 'n nuwe karaktertrek te onthul nie, maar om te help om 'n bepaalde gedragspatroon aan te dui: om uit die gesamentlike beurs te steel, om te maak of 'n mens vir armes omgee, maar eintlik iets heeltemal anders in gedagte te hê en om Jesus te verraai, is alles deel van dieselfde soort gedragspatroon. Derdens word Judas se optrede in hierdie toneel ook gekontrasteer met die optrede van Maria, aangesien dit twee heeltemal verskillende soorte reaksies op Jesus verteenwoordig. Beirne (2003:150) beskryf dit tereg as volg: "the goodness, openness and generosity of spirit of Mary of Bethany" teenoor "the secretiveness, venality and avarice of Judas".

In Johannes 13:2 word die leser se aandag weer eens op Judas gevestig as hy weer intern gefokaliseer word: wanneer die maaltyd begin, het die duiwel reeds vir Judas "in die hart ingegee" om Jesus

5 Die lesing tou'diabovou hah beblhkoto eij thn kardian i ha paradoi' a ut on Jouda Simwno Jskariwtou (d.w.s. met Jouda in die 
te verraai. Wat nuut in hierdie geval is, is die feit dat Judas nou direk met "die" duiwel verbind word. In 6:71 is Judas alreeds " $n$ " duiwel genoem, maar nou word sy komende verraad eksplisiet met die duiwel verbind met die gevolg dat die groter kosmiese dimensie nou bykom. Hy tree nie net op eie inisiatief op nie, maar word inderwaarheid deur die duiwel gebruik wat hom op hierdie stadium reeds op die gedagte gebring het om Jesus te verraai ${ }^{6}$.

In Johannes 13:11 is daar 'n verdere verwysing na Judas as die leser deur middel van 'n sydelingse opmerking verneem hoekom Jesus gesê het: "Julle is rein, maar nie almal nie." Hy het dit gesê omdat Hy vooraf geweet het wie Hom gaan verraai. Ten opsigte van die karakterisering van Judas word egter nie werklik iets nuuts bygevoeg nie; die klem val op Jesus se voorkennis.

In Johannes 13:18 word Judas nie eksplisiet genoem nie, maar dit is duidelik dat daar na hom verwys word: Jesus weet wie Hy gekies het; dit het gebeur sodat die Skrif vervul kan word. Dit word dan gevolg deur ' $n$ aanhaling uit Psalm 41(40):107': iemand wat sy brood eet, het sy hakskeen teen Jesus gelig. Deur hierdie vers word geen nuwe inligting aan die leser oorgedra nie, maar die afskuwelike aard van Judas se optrede word op 'n treffende manier belig.

nominatief en nie direk ná kardian nie) is die moeiliker lesing en lyk daarom na die oorspronklike lesing. Kyk Metzger (1971:239-240). Die sinstruktuur is lomp en mag die gevolg wees van 'n poging om te beklemtoon (Schnackenburg 1979:27). Hierdie lesing kan op twee maniere vertaal word: 1. Die duiwel het dit in sy eie hart ingegee om Jesus te verraai, byvoorbeeld Barrett (1978:439). 2. Die duiwel het dit in Judas se hart ingegee om Jesus te veraai. Laasgenoemde word deur die meeste uitleggers aanvaar. Kyk byvoorbeeld Haenchen (1980:455). Die feit dat beblhkoto aktief is, maak die eerste moontlikheid minder waarskynlik. Kyk Liddell \& Scott (1996:A6, B; p. 305).

6 Louw \& Nida (1988:\$30.29) verduidelik die betekenis van die idioom as volg:

"[T]o cause someone to think in a particular manner, often as a means of inducing some behavior - 'to make think, to fill the heart, to cause to decide"'.

7 Hierdie aanhaling kom nie direk uit die LXX nie. Volgens Menken (1996:123-138) is die rede hiervoor waarskynlik die feit dat die weergawe in die LXX die indruk kon skep dat Jesus onwetend mislei is - iets wat sou bots met die groot klem wat in die Johannesevangelie op Jesus se alwetendheid geplaas word. Volgens Menken het die outeur daarom liewer sy eie vertaling gemaak en is hy in die proses deur 2 Samuel 18:28 beïnvloed. 
In Johannes 13:27 word die verhouding tussen Judas en die duiwel (nou "Satan" genoem) weer belig. Judas word weer intern gefokaliseer. In hierdie geval word aan die leser onthul dat Satan in Judas ingevaar het nadat hy die stukkie brood by Jesus geneem het. In vergelyking met vers 2 is daar nou 'n definitiewe ontwikkeling ${ }^{8}$. In vers 2 word net gesê dat Satan vir Judas op die gedagte gebring het om Jesus te verraai. Nou word hy volledig deur die Satan bemeester. Dit word ook simbolies aangedui deurdat spesifiek vertel word dat Judas uitbeweeg in die nag in - simbolies van die bose waardeur hy oorweldig is.

In hierdie konteks kry ons ook weer 'n verwysing na die gemeenskaplike beurs wat deur Judas gedra is, aangesien daar vertel word dat die dissipels gedink het Jesus het vir Judas gevra om iets vir die fees te koop of dat hy iets vir die armes moet gaan gee omdat hy die beurs dra (13:29). Geen nuwe inligting word hierdeur aan die leser bekend gemaak nie, maar dit kan dalk as 'n herinnering dien aan die vroeëre toneel (12:6) waarin sekere negatiewe karaktertrekke van Judas uitgelig is. In elk geval, die leser weet wat Judas gaan doen en sal nie die ironiese moment in 13:29 mis nie: Judas is allesbehalwe op pad om iets goeds te gaan doen!

In Johannes 17:12 word Judas weer genoem. In sy gebed verwys Jesus na die feit dat Hy die dissipels bewaar het en dat nie een van hulle verlore gegaan het nie, eij mh;0] uip; thi a pwl ei $\sim$, i ha $h$ Jgraf $h ; p \mid h r$ whh $\not \partial$ Alhoewel Judas nie by die naam genoem word nie, is dit duidelik dat Jesus na hom verwys. Hierdie frase bring twee verdere dimensies in die karakterisering van Judas na vore. Eerstens is dit verreweg die mees negatiewe karakterisering van Judas in die Johannesevangelie. Die uitdrukking of uib; th $\sim$ apwlei $\sim$ wat in 2 Tessalonisense 2:3 gebruik word om na die Antichris te verwys, word nou gebruik om na Judas te verwys. Dié uitdrukking dra die konnotasie van veroordeling en uitsluiting uit die verlossing (Klauck 1987:87). Dit word binne hierdie konteks gebruik om die eskatologiese rol wat Judas vervul, uit te wys (Thyen 2005:695): in hierdie verhaal speel hy die rol van die eskatologiese

8 Johannes 13:27 word soms so geïnterpreteer asof dit 13:2 weerspreek. Kyk byvoorbeeld die bespreking by Schnackenburg (1979:17-18) en Brown (1984:563-564). Dit is egter nie noodwendig die geval nie. Klauck (1987:81) merk tereg op: "Nun ist der vorhandene Gegensatz nur relativ, nicht absolut. Zwischen Eingeben eines Planes und Besitzergreifen besteht ein Unterschied.” 
karakter wat moet verskyn voordat die heerlikheid van Jesus gemanifesteer word (Barrett 1978:508). Tweedens word Judas se lot weer aan God se wil gekoppel (kyk 13:18). Wat met hom gebeur het, het volgens God se wil gebeur - i ina h/graf $h ; p \mid h r w q h$ l

Judas verskyn die laaste keer in Johannes 18:2-69 . Hy word twee keer geïdentifiseer as "Judas wat Hom verraai het" ( | ouda 0) paradidou; a uf on; verse 2 en 5) en die rede hoekom hy geweet het waar om vir Jesus te vind, word gegee. Die belangrikste aspek is egter die feit dat Judas nou openlik van kant verwissel het: hy bring die magte van die duister (ironies met "lig" in die hand - lanterns en fakkels) na die plek waar hy weet Jesus en sy dissipels gekry kan word. Om die waarheid te sê, dit word spesifiek gesê dat hy nou "met hulle" is: eisthkei de; kai; Jouda ol paradidour aut on met' a uf. wh̀ (18:5). Soos Resseguie (2001:164) tereg opmerk, is die sirkel nou volledig voltooi: die eerste keer wat Judas as karakter in die vertelde wêreld genoem word, is hy saam met die twaalf (6:71: eif ek t wh dwdeka); die laaste keer wat hy optree, is hy saam met "hulle". Hy het nou openlik van kant verwissel.

Om saam te vat, die karakterisering van Judas in die Johannesevangelie is basies een-dimensioneel: hy is die dissipel wat sy Meester verraai, die verraderlike dief wat uit die gesamentlike beurs wat aan hom toevertrou is, steel, "'n" duiwel wat deur "die" duiwel op die gedagte gebring is om Jesus te verraai, die een wat, wanneer hy as verraaier geïdentifiseer word, die stukkie brood neem en heeltemal deur die Satan oorgeneem word, hy is die dissipel wat in die nag verdwyn om weer saam met die magte van die duisternis te verskyn, hy is die eskatologiese "seun van die verderf", bestem om verlore te gaan sodat die Skrif vervul kon word.

\section{DIE IDENTIFIKASIE VAN JUDAS AS VERRAAIER IN JOHANNES 13:21-30}

Wat is die doel van hierdie deel van die Johannesevangelie? Soos wat gewoonlik die geval in dié Evangelie is, val die klem op die Christologiese moment. In hierdie geval word die feit dat Jesus weet wat in die toekoms gaan gebeur, geïllustreer en so word sy identiteit

9 In Joh 21:10 kom Judas weer ter sprake as die 'geliefde dissipel' geïdentifiseer word as die een wat vir Jesus gevra het "kurie, ti es t in of paradidou $s$ e;" Judas verskyn self egter vir die laaste keer as 'n karakter in die vertelde wêreld in 18:2-6. 
as Seun van God beklemtoon. Dat Hy vooraf weet wat gaan gebeur, spesifiek dat Judas Hom gaan verraai, is reeds verskeie kere genoem (byv. 6:70-71; 13:3; 13:11 en and 13:18), maar in hierdie geval word sy voorafkennis op 'n dramatiese manier geïllustreer. In ooreenstemming met die Christologiese klem word Jesus nie net uitgebeeld as Iemand wat hierdie voorafkennis het en dit openbaar nie, maar ook as Iemand wat aktief gebeure in 'n bepaalde rigting stuur, veral deur sy woorde aan Judas "Doen gou wat jy gaan doen!" Hy word dus nie uitgebeeld as die slagoffer nie; Hy is die Een wat volledig in beheer van gebeure is; nie Judas of die Satan nie! (Becker 1981:433$434)^{10}$.

Afgesien van die Christologiese klem kan 'n mens ook sekondêre motiewe in hierdie gedeelte aandui. Een hiervan is dat die afskuwelikheid van Judas se daad weer eens beklemtoon word. Dit word gedoen deurdat vertel word dat Jesus "in sy gees ontsteld geword het" 11 toe Hy die aankondiging gemaak het $(13: 21)$. Dit is een van die min geleenthede in die Johannesevangelie waar Jesus emosie wys ${ }^{12}$. 'n Verdere interessante aspek is dat dit juis hierdie toneel is wat gebruik word om die Geliefde Dissipel die eerste keer te laat optree. Gebeur dit dalk omdat dit so 'n uitstekende geleentheid bied om hierdie ideale dissipel met sowel Petrus (wie se faling in die volgende toneel belig word) as Judas te kontrasteer?

Voordat ons die betekenis van die gebaar waarmee Jesus vir Judas identifiseer, van nader ondersoek, is daar 'n ander aspek wat aandag moet kry omdat dit van belang kan wees vir die interpretasie van Jesus se gebaar. Een van die aspekte in 13:21-30 wat gereeld in kommentare bespreek word, is tot watter mate die gebeure wat hier vertel word, 'n realistiese uitbeelding is. Met ander woorde, die vraag is of dinge gewoonlik gebeur soos wat dit hier vertel word. Die probleem word veroorsaak deur vers 28 waarvolgens nie een (oujeił) van die dissipels verstaan het hoekom Jesus vir Judas aangepor het om gou te mak nie. Sommige navorsers probeer sin

10 Wellhausen (1908:60-61) interpreteer 13:26 as 'n aanduiding dat Jesus veroorsaak het dat die Satan in Judas invaar, maar so 'n kousale verband word nie in die teks aangedui nie, aangesien met a V'n temporele en nie noodwendig 'n kousale verband aandui nie.

11 Louw \& Nida (1988:\$25.244) verduidelik die betekenis van die uitdrukking as 'n aanduiding van "acute emotional distress or turbulence".

12 Vir ander gevalle, kyk Joh 11:33 and 12:27. 
maak van die gebeure deur aan te neem dat die Geliefde Dissipel vir Jesus gefluister het en Jesus vir hom terug gefluister het en dat die ander dissipels daarom nie besef het wat hulle vir mekaar sê nie (Carson 1991:474). Dan moet 'n mens natuurlik ook aanvaar dat nie een van die dissipels gesien het hoe Petrus vir die Geliefde Dissipel knik om vir Jesus te vra van wie Hy praat nie - wat moeilik voorstelbaar is aangesien vers 22 op 'n geskokte stilte dui waartydens hulle mekaar aangestaar het. In elk geval, selfs indien die ander dissipels nie gehoor het wat die Geliefde Dissipel en Jesus vir mekaar sê nie, moes ten minste die Geliefde Dissipel (en moontlik ook Petrus) begryp het waarom Jesus dit vir Judas gesê het.

Om hierdie dilemma te probeer verklaar, is daar al verskeie voorstelle gemaak: Dat sommige van die dissipels wel besef het dat dit Judas is wat vir Jesus gaan verraai, maar dat hulle net nie kon glo dat Jesus hom sou vra om dit gou te gaan doen nie (Zahn 1986:545); dat die Geliefde Dissipel die betekenis van Jesus se handeling begryp het, maar dat hy van skok vir 'n paar oomblikke verlam ("paralysed") was en niks kon doen nie (Carson 1991:474); dat die Geliefde Dissipel Jesus se handeling begryp het, maar nie sy woorde verstaan het nie (Barrett 1978:448); of dat vers 28 so verstaan moet word dat dit die Geliefde Dissipel en Petrus uitsluit (Brown 1984:575). Ander kenners sê onomwonde dat die toneel ongeloofwaardig is (Haenchen 1980:465-466), terwyl andere die probleem weer toeskryf aan redaksionele aktiwiteit (Bultmann 1978:366-367 ). Dit lyk egter of ' $n$ mens nie anders kan as om die woorde in vers 28 op sigwaarde te neem en te aanvaar dat dit beteken wat dit ooglopend sê nie: Nie een van die dissipels, ook nie die Geliefde Dissipel en Petrus, het verstaan wat aan die gang was nie. Dit lyk ongeloofwaardig, maar 'n mens moet besef dat hier gebruik gemaak word van 'n geliefkoosde Johannese tegniek, naamlik misverstand (Culpepper 1983:152-165). Die gebruik van hierdie tegniek het uiteraard 'n effek op die geloofwaardigheid van die toneel, maar dit kan nie anders nie. Schnackenburg (1979:36) verduidelik tereg:

[Dann] wird es auch begreiflich, warum weder Petrus noch jener Jünger etwas unternimmt. Darüber reflektiert der Evangelist nicht, sie haben ihre Funktion erfüllt. Freilich verliert die Szene dadurch ihre historische Glaubwürdigkeit, aber diese Art, theologische Gedanken in einem Geschehen darzustellen, lebendig-dramatisch 
vor Augen zu führen, mu $\beta$ man als Stilmittel des Evangelisten anerkennen.

Laat ons nou die betekenis van Jesus se gebaar ondersoek. Dit is welbekend dat gebare kultureel-spesifiek is en dat dieselfde gebaar op verskille maniere in verskillende kulture verstaan kan word. Wat is die kulturele agtergrond vir Jesus se gebaar? Die gewildste interpretasie is dat dit 'n gebaar van gasvryheid is. 'n Voorbeeld van so 'n interpretasie, is dit wat Brown (1984:578) daaroor skryf: "What John describes is a basic gesture of Oriental hospitality, as can be seen from Ruth ii 14." Brown is egter nie korrek as hy Rut 2:14 as bewys vir sy stelling aanvoer nie omdat daar iets anders as in Johannes 13:26 gebeur. In die geval van Rut 2:14 nooi Boas vir Rut: "Kom hierheen en eet van die brood en doop jou stukkie kos in die suur wyn." In die LXX lui Boas se woorde aan Rut as volg: Hdh wha tou'fagein prosel qe whle kai; fagesai twh altwn kai; bay ei t on y wmom sou ej t wǒkei. Alhoewel daar ooreenkomste tussen Rut 2:14 en Johannes 13:26 is, naamlik die gebruik van bapt $W$ in beide gevalle en amper dieselfde woord vir "stukkie kos" (y wmo in Rut $2: 14$ en y wmi on $^{13}$ in Johannes 13:26), is dit wat in Rut 2:14 uitgebeeld word nie dieselfde gebaar as in Johannes 13:26 nie. Boas doop nie 'n stukkie kos in sous en gee dit vir Rut nie, maar nooi haar uit om haar stukkie kos in die suur wyn te kom doop. In Rut 2:14 val die klem op Boas se gasvryheid (Bush 1996:128-129). Dit illustreer ook hoe belangrik die deel van voedsel binne 'n vriendskapskonteks is - iets wat as algemene agtergrond vir Johannes 13-17 kan dien, veral as 'n mens Johannes 15:15 in gedagte hou. Dit bied egter nie inligting uit die antieke wêreld wat ons help om Jesus se gebaar in Johannes 13:26 te interpreteer nie.

Brown motiveer nie sy stelling dat Jesus se gebaar Oosterse gasvryheid aandui nie. Dit is moontlik dat hy sy inligting uit vroeëre kommentare kry en dit dus nie nodig vind om enige redes vir sy stelling te gee nie. Die vroegste soortgelyke interpretasie van Jesus se gebaar wat ek in 'n kommentaar op die Johannesevangelie kon opspoor, is dié van Westcott (1971:194; oorspronklik in 1881

13 y wmi on, die verkleiningsvorm van y wmo $\forall$, kom in die Nuwe Testament slegs in Johannes 13 voor; nooit in die LXX nie. Dit kom wel in enkele gevalle in papiri voor (kyk BDAG y wmi on). In die LXX kom y wmo $\nleftarrow$ wel verskeie keer voor (Lust et al. 1996:525). Kyk ook Liddell \& Scott (1996:318 [Supplement]) vir ander gevalle waar dit ook gebruik word om na 'n stukkie brood te verwys. 
gepubliseer). Hy verbind die gebaar egter nie direk aan Rut 2:14 nie, maar dui net aan "cf. Ruth 2:14" en verwys dan na 'n huidige gebruik:

It is an Eastern custom at present for the host to give a small ball of meat to the guest whom he wishes to honour. The reference may be to this custom (My beklemtoning; DFT.).

Sewe-en-veertig jaar later was Bernard (1949:473-474; oorspronklik in 1928 gepubliseer) egter baie sekerder van sy saak:

It was a token of intimacy, to allow a guest to dip his bread in the common dish or trublion: thus Boaz says to Ruth bay ei ton y wmon t wǒkei (Ruth $2^{14}$ ). And it is still a favour of Eastern hospitality for the host to dip a choice morsel in the central dish and hand it to a guest. This is what Jesus did for Judas, who was probably reclining at table next to Him...; but it was so usual a courtesy that it escaped the notice of the others...

Dit lyk asof Westcott se "miskien" ("may be") intussen 'n "feit" in Johannesnavorsing geword het en dit kon moontlik vir Brown beïnvloed het. Natuurlik beteken dit nie dat Westcott, Bernard, Brown en andere wat soos hulle dink, noodwendig verkeerd is nie; net dat ek nie enige getuienis uit die antieke wêreld kon vind om hierdie keuse te ondersteun nie ${ }^{14}$. Westcott se stelling dat die gebaar in die moderne wêreld op so 'n manier funksioneer, kan wel maklik bevestig word $^{15}$. Alhoewel ek nie soortgelyke inligting uit die

14 Die Kerkvaders verwys na of bespreek Johannes 13:26 by geleentheid, maar so ver ek kon vasstel, verwys hulle nie na die betekenis van die gebaar as sodanig nie. Kyk Origenes ComIo 32.22; Hieronimus Ep 125.1, Augustinus Harm 3.1.3, TracIo 61.6, 62.1. Johannes Chrysostomus HomIo 122.2 sê wel dat die manier waarop die verraaier aangewys word, gepas was om iemand skaam te maak (ejt r ept i ko $\forall$ ), maar bespreek nie die gebaar nie. Strack \& Billerbeck (1983:559) bespreek glad nie hierdie vers nie.

15 Op die internet kry 'n mens maklik inligting om dit te bevestig. Kyk byvoorbeeld na die volgende webwerwe (afgelaai op 1 Maart 2007) waaruit dit duidelik blyk dat hierdie gebaar in ons tyd in verskillende kulture op so 'n manier funksioneer: die Midde-Ooste (http://ismaili.net/timeline/95.html), Etiopië (http://www.metroactive.com/papers/metro/07.23.98/dining-9829. html), die Moslemwêreld (http://www.global-prayer-digest.org/monthdetails/ 2005/md-May-2005.asp) en selfs China (http:// www.bosstops.com/asp/news/ ShowLeft.asp?Cid= 94\&Id=459). 
antieke wêreld kon kry om dit te bevestig nie, maak dit wel sin om die gee van 'n stukkie brood deur die gasheer aan een van die gaste as 'n gebaar met 'n positiewe bedoeling te interpreteer, want dit is basies 'n gebaar van voeding - iets wat op sorg dui ${ }^{16}$. Die volgende voorbeelde uit die wêreld van die Bybel bevestig die positiewe konnotasies wat destyds met die konsep van voeding geassosieer is: die Here wat sy volk in die woestyn voed (Deuteronomium 8:14 y wmi $\mathbb{w}$ ) of wat belowe om hulle met die "erfdeel van hulle voorvader Jakob te voed" (Jesaja 58:14 - y qmi z w); Wysheid wat die mense voed wat die Here respekteer en wat die wet onderhou (Sirag 15:13 - y wmi $\mathbb{z}$; ' 'n skoonpa wat sy skoonseun iets te eet aanbied (Rigters 19:5 - y wmot a [ t ou; 'n vrou wat 'n medium is wat vir Saul kos aanbied (1 Samuel 28:22 - ywmov a[tou); Tamar wat vir Amnon voed (2 Samuel 13:5; y wmi $\mathbb{z} w$ ); en 'n bereidheid om 'n mens se vyande te voed (Romeine 12:20 - y wmi z w).

Afgesien van die positiewe assosiasies wat met 'n gebaar wat op voeding dui, gepaard gaan, is dit ook belangrik dat ons in gedagte sal hou hoe belangrik die voedingskonsep in die Johannesevangelie is. Soos Van der Watt (2000:216-235) in sy gedetailleerde studie van metafore in hierdie Evangelie aandui, word verwysings na eet en drink gebruik om die ondersteuning van lewe metafories aan te dui'n belangrike faset van die groter netwerk van metafore in dié Evangelie. Brood, water en wyn word byvoorbeeld gebruik om op Jesus as Gewer van lewe te dui. As die feit dat Jesus in Johannes 13 vir Judas 'n stukkie brood gee, teen die agtergrond van hierdie groter metaforiese netwerk in die Evangelie geïnterpreteer word, kan 'n mens dit dus met reg as 'n gebaar met 'n positiewe betekenis interpreteer. Meer spesifiek: Indien 'n mens die positiewe manier waarop brood en die voorsiening van brood in Johannes 6 uitgebeeld word, in gedagte hou, is dit moeilik om te aanvaar dat die gee van 'n stukkie brood deur Jesus, die Brood van die Lewe, aan een van sy dissipels in Johannes 13 primêr as 'n gebaar met 'n negatiewe konnotasie geïnterpreteer moet word soos wat Hirsch (1936:338339) beweer. So 'n interpretasie bots met die manier waarop voedingsmetafore in die res van die Evangelie gebruik word. Dit is wel waar dat die gebaar 'n negatiewe effek op Judas het in die sin

16 Brood is gewoonlik in die antieke wêreld op 'n positiewe manier geïnterpreteer. Kyk Chevalier \& Gheerbrandt (1996:118) en Lurker (1983:105106). 
dat sy planne aan die kaak gestel word, maar dit beteken nie dat die gebaar as sodanig negatief geïnterpreteer moet word nie.

Om Jesus se gebaar te verstaan, moet 'n mens egter nie net die breë metaforiese netwerk in die Johannesevangelie as geheel in gedagte hou nie, maar ook die nadere konteks waarbinne dit voorkom. In hierdie geval is dit veral vers 18 wat ook in ag geneem moet word. In vers 18 verwys Jesus na die feit dat die Skrif vervul moet word en haal dan 'n spesifieke vers aan: of trwgwn mou t on alton ephren ep' eme; thn pternan autou. Soos reeds in die vorige afdeling aangetoon is, val die klem veral op die verraderlike aard van die gedrag wat ter sprake is, veral die "eet van my brood" teenoor die "oplig van sy hakskeen teen My". Kort hierna gee Jesus vir Judas 'n stukkie brood. Sy gebaar illustreer - 'n mens kan dalk selfs sê "vervul" - die eerste deel van die aanhaling op 'n aanskoulike manier. Deur vir Judas die stukkie brood te gee wat Hy in sy hand het ${ }^{17}$ - met ander woorde, 'n stukkie van "my brood" wat dan deur Judas geëet ${ }^{18}$ word, speel die woorde van vers 18 voor die oë van die dissipels - en as’t ware voor die oë van die leser - af. Natuurlik moet ons aanvaar dat Judas en die ander dissipels gereeld saam met Jesus geëet het en dat dit ook nie die eerste keer daardie aand was dat iemand saam met Jesus geëet het nie, maar dit is wel die eerste keer ná vers 18 dat die leser se aandag spesifiek daarop gevestig word.

Moet ons hierdie interpretasie verder neem? Is Jesus se gebaar meer as net 'n gebaar van voeding en sorg? Is dit soos wat Brodie (1993:453) beweer, 'n poging "to recall Judas from his developing entanglement with Satan"? Is Jesus se bedoeling dus om te probeer om Judas te oorreed om nie voort te gaan met dit wat hy beplan nie? So ' $n$ interpretasie lyk baie aanloklik, maar ongelukkig bots dit met die narratiewe logika van die Johannesevangelie. Soos ek hierbo aangedui het, word Jesus deurgaans uitgebeeld as volledig bewus van wat in die toekoms gaan gebeur, nie net in die sin dat Hy gaan terugkeer na sy Vader toe nie (Johannes 13:1), maar ook in die sin dat Hy vooraf weet dat Judas Hom gaan verraai. Dit word verskeie

17 Zahn (1986:544) wys tereg daarop dat die lidwoord saam met y wmi on gebruik word en dat dit as 'n aanduiding kan dien dat Jesus reeds die stukkie brood in sy hand het wanneer Hy op die Geliefde Dissipel se versoek reageer.

18 Dit word nie spesifiek gesê dat Judas die stukkie brood geëet het nie, maar dit word deur die woorde met a; 0 ; y wmi on geïmpliseer. 
kere vóór die toneel in Johannes 13:21-30 genoem. Om die waarheid te sê, volgens 13:18 (herhaal in 17:9) is dit wat met Judas gaan gebeur, 'n vervulling van 'n goddelike plan (i ía h) graf $h$; pl hrwqh\%. As Jesus dus nou sou probeer om Judas te oortuig om nie voort te gaan met dit wat hy beplan nie, sou Hy nie net handel téén dit wat Hy self vooraf weet gaan gebeur nie, maar ook téén die goddelike plan. Sy optrede sou inderdaad skynheilig wees omdat Hy sou probeer om iets te doen wat in terme van dit wat reeds aan die leser bekend is, onmoontlik kan gebeur. As daar 'n moontlikheid was dat Judas in hoofstuk 13 nog verhoed kon word om Jesus te verraai, sou dit wat oor hom in hoofstukke 1-12 gesê word, nie meer waar wees nie. In terme van die narratiewe logika van die Johannesevangelie sou dit dus verkeerd wees om Jesus se gebaar te interpreteer as 'n poging om Judas te verhoed om te doen wat sowel Jesus as die leser reeds weet hy gaan doen.

Indien die teks ons nie toelaat om Jesus se gebaar te interpreteer as ' $n$ poging om Judas te verhoed om Jesus te verraai nie, wat van die moontlikheid om die gebaar sakramenteel te interpreteer? Dit is nie so 'n maklike vraag om te beantwoord nie. 'n Mens se antwoord hierop word tot 'n groot mate beïnvloed deur 'n mens se siening hoe belangrik die sakramente in die Johannesevangelie is en dit is 'n saak waaroor daar heelwat verskil van opinie is. $\mathrm{Na}$ my oordeel is dit die beste om te aanvaar dat die sakramente slegs op 'n indirekte manier in die Johannesevangelie funksioneer (Beasley-Murray 1991:87); as't ware op die agtergrond is (Koester 1995:257-262).

Is daar enige aanduidings in Johannes 13 dat ons hierdie hoofstuk primêr sakramenteel moet lees? Laat ons eers die interpretasie ondersoek wat op die Nagmaal fokus. Die grootste struikelblok vir so ' $n$ interpretasie is dat die instelling van die Nagmaal glad nie in hierdie hoofstuk (of op enige ander plek in die Evangelie) vertel word nie. Ten spyte daarvan sou 'n mens wel drie ander argumente kon noem wat só 'n interpretasie van Johannes 13:21-30 kon ondersteun: Eerstens sou 'n mens kon argumenteer dat die vorige toneel (die voetewassing) in vers 10 aan die doop gekoppel word. Tweedens het Moloney (1998:21-22) uitgewys dat die woord trwgwn wat in vers 18 gebruik word, nie die normale woord vir eet in die Evangelie is nie en dat dit slegs in een ander deel van die Evangelie gebruik word, naamlik in 6:51c-58, 'n 
gedeelte waar ' $n$ mens definitiewe sinspelings op die Nagmaal kry. Die derde argument kom ook van Moloney (1998:22). Hy wys daarop dat vers 26 die woorde "en Hy neem" bevat (bay a ouh t 0 ; y wmion Iambanei kai; didws in Joudabsimwno Jskariwtou woorde wat in die broodwonder in al vier die Evangelies gebruik word en waarskynlik Nagmaalpraktyke in die vroeë kerk reflekteer. Hierdie argument is egter nie so sterk as wat dit klink nie omdat dit nie seker is of die woorde lambanei kaiv wel deel van die oorspronklike teks was nie ${ }^{19}$. Ek vind dit makliker om te verklaar hoekom dit bygevoeg is as hoekom dit weggelaat is. In elk geval, selfs al sou ons dit as deel van die oorspronklike teks beskou, het ons net drie woorde in Johannes 13 wat as 'n teken aan die leser moet funksioneer dat die brood wat Jesus in vers 26 aan Judas gee, as die sakrament van die Nagmaal verstaan moet word: $t r w g$ wn in vers 18 en I a mbanei kaivin vers 26. Dit is natuurlik nie onmoontlik nie, maar 'n mens moet tog die kritiese vraag vra of ons op grond daarvan vers 26 'n "Nagmaalteks" kan noem. Ek is van oordeel dat dit nie korrek is om dit te doen nie. 'n Mens sou hoogstens kan sê dat die Nagmaal as agtergrond vir die gebeure in hoofstuk 13 dien, maar om dit as die primêre verwysing van Jesus se gebaar in vers 26 te beskou, kan nie uit die teks verantwoord nie. Wanneer 'n mens die gebaar as 'n aanduiding beskou dat Jesus vir Judas uitnooi om Nagmaal te gebruik of as 'n mens nog 'n stap verder gaan en argumenteer dat Judas nie Nagmaal met Jesus nie, maar wel met Satan geniet (Talbert 1992:198) of dit selfs as "eine Art satanisches Sakrament" (Wrede 1907:136) beskou, is 'n mens besig om dit wat hoogstens as die agtergrond van die gebeure beskou word, te verhef tot die primêre verwysing van die gebaar.

Die bewyse wat vir 'n doop-interpretasie van die gebaar aangevoer word, is selfs nog minder as die vir 'n Nagmaalinterpretasie. Howard-Brook (1994:304) verbind die gebaar aan die doop, maar gee nie spesifieke redes daarvoor nie. Hy verwys wel daarna dat Jesus die stukkie brood "doop", asook die feit dat dit tot gevolg het dat die Satan in Judas invaar. Buckley $(1998: 62,67)$

19 Dit word in vierkantige hakies in $\mathrm{UBS}^{4 \mathrm{Her}}$ en Nestle-Aland ${ }^{27}$ geplaas. Volgens Metzger (1971:241) het die komitee dit moeilik gevind om te besluit of dit bygevoeg is deur kopieerders op grond van dit wat elders in die Evangelies voorkom en of dit weggelaat is omdat dit as onnodig beskou is. Daarom het die meerderheid van die komitee besluit om dit in vierkantige hakies te plaas. 
baseer sy doop-interpretasie van die gebeure daarop dat die woord wat in vers 26 gebruik word, volgens hom, dieselfde woord is as wat vir doop (sakrament) gebruik word. Dit is egter nie waar nie. Die woord wat in hierdie geval vir doop gebruik word (bapt w, word nooit in die Nuwe Testament vir die doop as sakrament gebruik nie. Dit laat ons dus bloot met Jesus se doop-aksie in vers 26 as 'n moontlike teken vir die leser dat Jesus se gebaar na die doop as sakrament verwys. Dit is 'n maar 'n swakkerige tekstuele basis om vir 'n doop-interpretasie aan te voer.

Verder is sowel Howard-Brook as Buckley verkeerd as hulle die eet van die stukkie brood verbind aan die feit dat Satan in Judas invaar. Soos reeds vroeër aangedui is ${ }^{20}$, is dit nie korrek om 'n kousale verband tussen die eet van die stukkie brood en Satan se invaar in Judas te plaas nie omdat met avt 0; y wmi on 'n temporele ("nadat") en nie 'n kousale relasie aantoon nie. Die afwesigheid van só 'n kousale relasie impliseer ook dat Buckley se interpretasie van die toneel as 'n vergiftigingstoneel geen tekstuele basis het nie.

Om Johannes 13:26 dus sakramenteel, hetsy as 'n verwysing na die Nagmaal, hetsy as 'n verwysing na die doop, te interpreteer, kan nie oortuigend uit die teks gemotiveer word nie. Wat wel uit die teks gemotiveer kan word, is ' $n$ interpretasie van die gebaar wat die metaforiese netwerk in die Evangelie as geheel in ag neem. Teen so 'n agtergrond kan die gebaar as 'n voedingsgebaar (met al die metaforiese ondertone daaraan verbonde) geïnterpreteer word. Binne die spesifieke konteks dien dit as 'n ontstellende uitbeelding van hoe Judas "Jesus se brood" eet. Indien die feit dat dit alles binne 'n vriendskapskonteks afspeel (soos bo aangetoon) ook in ag geneem word, word die verraderlike aard van Jesus se optrede verder deur Judas se gebaar onderstreep.

'n Laaste suggestie: Miskien moet 'n mens een verdere moontlikheid oorweeg. Moet die feit dat dit spesifiek 'n voedingsgebaar is wat deur die Johannese Jesus gebruik word om die verraaier uit te wys, nie moontlik as 'n verdere geval van die kenmerkende Johannese ironie beskou word nie? As ons ironie definieer as 'n inkongruensie tussen voorkoms en werklikheid

20 Kyk voetnoot 10. 
waarvan die slagoffer (in hierdie geval Judas) nie bewus is nie ${ }^{21}$, is dit presies wat ons hier het: Jesus, die Brood van die Lewe, die Een wat geestelike lewe gee, gee 'n stukkie fisiese brood aan iemand wat fisies lewe, maar geestelik dood is. Hierdie persoon neem en eet die brood, d.w.s. hy kry fisiese voeding, maar geen geestelike voeding nie $^{22}$. Hy ontvang dus brood, maar nie lewe nie. Vanuit hierdie perspektief beskou kan Jesus se gebaar dus as 'n ironiese handeling getipeer word. Saam met die ander tipiese Johannese tegniek wat ook in hierdie gedeelte gebruik word en reeds hierbo uitgewys is as 'n tegniek wat ironies funksioneer, naamlik die misverstand oor wat Judas op pad is om te gaan doen (13:29), sal Jesus se ironiese gebaar 'n besliste effek op die leser hê. Dit beklemtoon die ontstellende werklikheid dat sommige mense wat baie naby aan Jesus was, nie verstaan het nie en dat een van hulle nie die lewe gekry het nie. Op dié manier word die leser aangespoor om nie net naby Jesus te wees nie, maar ook om te verstaan en werklik die lewe van Jesus te ontvang. Dit wat Busse (2002:211) oor die gebruik van die tegniek van misverstand in hierdie hoofstuk geskryf het, kan net so op Jesus se ironiese gebaar in vers 26 van toepassing gemaak word. Dit is 'n "literêre instrument"

... mit dessen Hilfe der Erzähler immer erneut den Erfahrungshorizont des Lesers ins Visier nimmt, theologisch weitet und ihm Orientierung für die eigene Gegenwart anbietet.

\section{Literatuurverwysings}

Barrett, C K 1978. The Gospel according to St John. An introduction with commentary and notes on the Greek text. London: SPCK.

Beasley-Murray, G R 1991. Gospel of Life. Theology in the Fourth Gospel. Peabody: Hendrickson.

Becker, J 1981. Das Evangelium nach Johannes. Kapitel 11-21 (ÖTK 4/2). Gütersloh: Echter Verlag.

Beirne, M M 2003. Women and men in the Fourth Gospel. A genuine discipleship of equals (JSNT Sup 242). Sheffield: Sheffield Academic Press.

21 Kyk Culpepper (1983:166-167) en Resseguie (2001:28-30) hieroor. Vir 'n goeie oorsig van die navorsing oor Johannese ironie, kyk Culpepper (1996:193-207).

22 Dieselfde gebeur wanneer Jesus Judas se voete was. Sy voete word fisies gewas, maar hy bly onrein (Joh 13:10). 
Bernard, J H 1949. A critical and exegetical commentary on the Gospel according to St. John (CEC 2). Edinburgh: T \& T Clark.

Bohnen, J 2000. 'Watch how you're eating': Judas and Jesus and table manners. An intertextual reading of John 13:26; Matthew 26:23 and Sirach 31:12-32:13. Scriptura 74, 259-283.

Brodie, T L 1993. The Gospel according to John. A literary and theological commentary. New York - Oxford: Oxford University Press.

Brown, R E 1984. The Gospel according to John. Volume 2 (xiii-xxi). London: Geoffrey Chapman.

Buckley, J J 1998. Presenting the poison in the Gospel of John. In: Pippin T \& Aichele, G (reds.), Violence, utopia, and the Kingdom of God. Fantasy and ideology in the Bible. London - New York: Routledge, 60-71.

Bultmann, R 1978. Das Evangelium des Johannes (KEK 19). Göttingen: Vandenhoeck \& Ruprecht.

Bush, F W 1996. Ruth, Esther (WBC 9). Dallas: Word Books.

Busse, U 2002. Das Johannesevangelium. Bildlichkeit, Diskurs und Ritual. Mit einer Bibliographie über den Zeitraum 1986-1998 (BETL 162). Leuven Paris - Sterling: Peeters.

Carson, D A 1991. The Gospel according to John. Leicester: Inter-Varsity Press.

Chevalier, J \& Gheerbrandt, A 1996. A dictionary of symbols. Translated from the French by John Buchanan-Brown. London: Penguin Books.

Culpepper, R A 1983. Anatomy of the Fourth Gospel. A study in literary design. Philadelphia: Fortress.

-, 1996. Reading Johannine irony, in: Culpepper R A \& Black, C C (reds.), Exploring the Gospel of John. In honor of D Moody Smith. Louisville: Westminster John Knox, 193-207.

Haenchen, E 1980. Das Johannesevangelium. Ein Kommentar aus den nachgelassenen Manuskripten herausgegeben von Ulrich Busse mit einem Vorwort von James M. Robinson. Tübingen: J C B. Mohr (Paul Siebeck).

Hirsch, E 1936. Das vierte Evangelium, in seiner ursprünglichen Gestalt verdeutscht und erklärt. Tübingen: Mohr.

Howard-Brook, W 1994. Becoming Children of God. John's Gospel and radical discipleship (The Bible \& Liberation Series). Maryknoll: Orbis.

Klauck, H-J 1987. Judas - Ein Jünger des Herrn. Freiburg - Basel - Wien: Herder.

Koester, C R 1995. Symbolism in the Fourth Gospel. Meaning, mystery, community. Minneapolis: Fortress.

Liddell, H G \& Scott, R 1996. A Greek-English lexicon. With a revised supplement. Oxford: Clarendon. 
Louw, J P \& Nida, E A 1988. Greek-English lexicon of the New Testament based on semantic domains. Volume 1. Introduction and domains. New York: United Bible Societies.

Lurker, M 1983. Wörterbuch der Symbolik. Stuttgart: Alfred Kröner.

Lust, J, Eynikel, E \& Hauspie, K 1996. A Greek-English lexicon of the Septuagint. Stuttgart: Deutsche Bibelgesellschaft.

Malina, B J \& Rohrbaugh, R L 1998. Social-Science Commentary on the Gospel of John. Minneapolis: Fortress.

Menken, M J J 1996. Old Testament quotations in the Fourth Gospel. Studies in textual form. Kampen: Kok Pharos.

Metzger, B M 1971. A textual commentary on the Greek New Testament. A companion volume to the United Bible Societies' Greek New Testament (Third edition). Stuttgart: United Bible Societies.

Moloney, F J 1998. Glory not dishonor. Reading John 13-21. Minneapolis: Fortress Press.

Resseguie, J L 2001. The strange gospel. Narrative design and point of view in John (BIS 56). Leiden - Boston - Köln: Brill.

Schnackenburg, R 1979. Das Johannesevangelium. III. Teil (HThK IV/I). Freiburg - Basel - Wien: Herder.

Staley, J L 1988. The print's first kiss: a rhetorical investigation of the implied reader in the Fourth Gospel. Atlanta: Scholars Press.

Strack, H L \& Billerbeck, P 1983. Kommentar zum Neuen Testament. Zweiter Band. Das Evangelium nach Markus, Lukas und Johannes und die Apostelgeschichte. München: C.H. Beck.

Talbert, C H 1992. Reading John. A literary and theological commentary on the Fourth Gospel and the Johannine Epistles. New York: Crossroad.

Thyen, H 2005. Das Johannesevangelium (HNT 6). Tübingen: Mohr-Siebeck.

Tolmie, D F 1999. Narratology and Biblical narratives. A practical guide. San Francisco - London - Bethesda: International Scholars Publications.

Van der Watt, J G 2000. Family of the King. Dynamics of metaphor in the Gospel according to John (BIS 47). Leiden: Brill.

Wellhausen, J 1908. Das Evangelium des Johannes. Berlin: Georg Reim.

Westcott, B F 1971. The Gospel according to St. John. The Authorized Version with introduction and notes. Grand Rapids: WM. B. Eerdmans.

Wrede, W 1907. Vorträge und Studien. Tübingen: J.C.B. Mohr (Siebeck).

Zahn, T 1986. Das Evangelium des Johannes. Wupperthal: R. Brockhaus. 